\title{
The classic pellagra dermatitis
}

\author{
Sharath P Madhyastha 이, ${ }^{1}$ Ganesh V Shetty, ${ }_{1}^{1}$ Varsha M Shetty, ${ }_{1}^{2}$ Charan T Reddy ${ }^{1}$
}

${ }^{1}$ Internal Medicine, Kasturba Medical College, Manipal Academy of Higher Education, Manipal, Karnataka, India ${ }^{2}$ Dermatology, Kasturba Medical College, Manipal Academy of Higher Education, Manipal, Karnataka, India

\section{Correspondence to}

Dr Sharath P Madhyastha; dr.sharathymc@gmail.com

\section{Accepted 8 October 2020}

\section{DESCRIPTION}

A 38-year-old woman presented with dry, cracked and hyperpigmented skin lesions over bilateral upper limb, neck and feet (figures 1-3, respectively) since 4 months. The skin lesions were localised to sun-exposed areas of the body indicating photosensitivity. The classical appearance of dermatitis and its distribution over the sunexposed area confirms the diagnosis of pellagra.

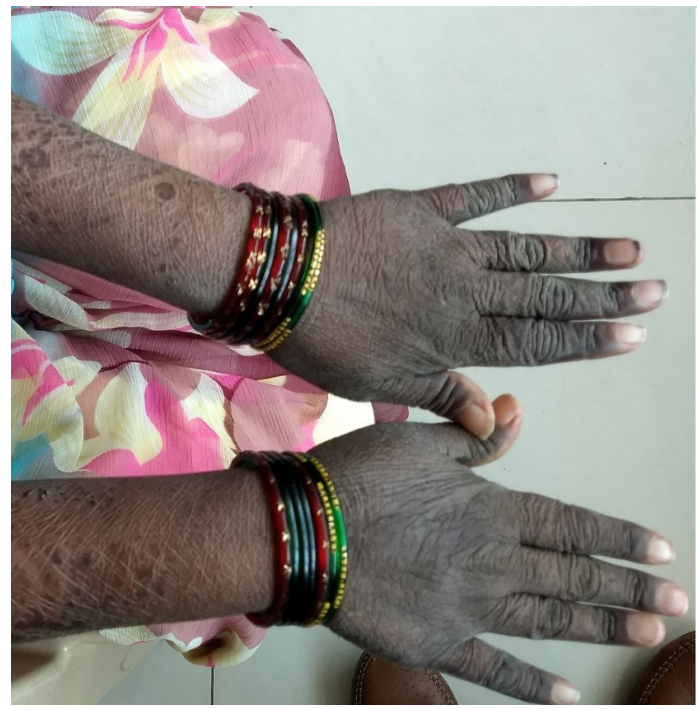

Figure 1 Clinical image showing the dry, cracked and hyperpigmented skin lesions over the sun-exposed area of the forearm.

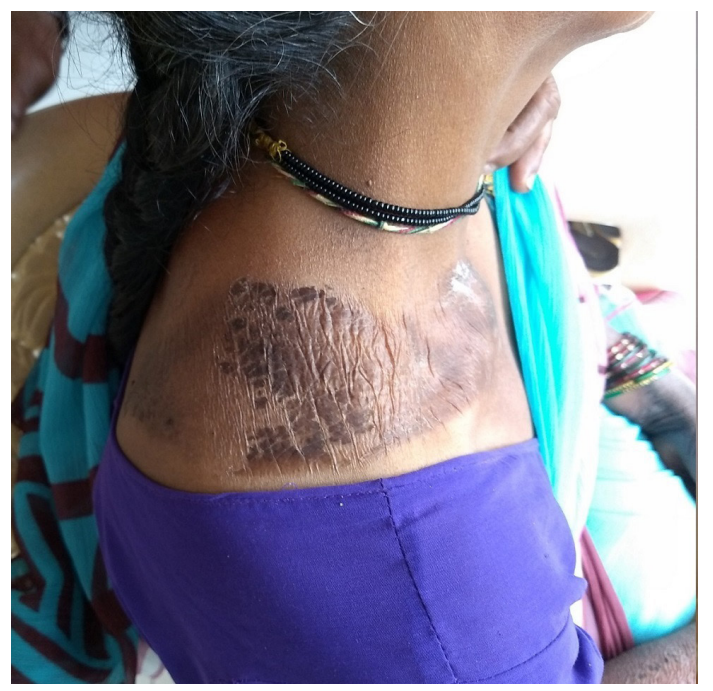

Figure 2 Clinical image showing the broad hyperpigmented band or collar-like appearance of pellagra on the neck. This is commonly referred to as 'Casal's necklace'.

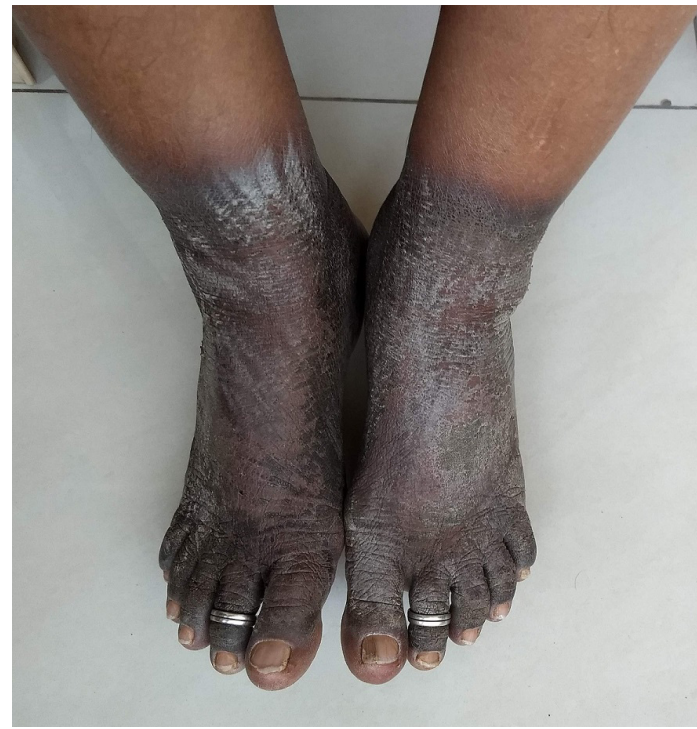

Figure 3 Clinical image showing the classical pellagra dermatitis over sun-exposed area of the lower limb with a clear cut-off at the margins of clothing.

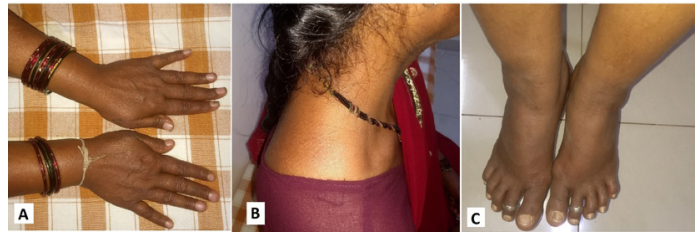

Figure 4 Clinical images showing the complete recovery of dermatitis after niacin supplementation: $(A)$ forearm, (B) neck and (C) lower limb.

She reported burning sensations over these lesions and no diarrhoea or neurological symptoms. Her dietary habits were reported to be poor because of alcohol addiction.

Niacin (vitamin $\mathrm{B}_{3}$ ) is an essential nutrient involved in the synthesis and metabolism of carbohydrates, fatty acids and proteins. Niacin deficiency causes pellagra (meaning 'raw skin'),

\section{Learning points}

- Niacin deficiency leading to pellagra continues to be a health problem in resource-limited countries.

- Clinical features are dermatitis, diarrhoea, dementia and, if left untreated, death (the often quoted '4 Ds').

- Pellagra is a clinical diagnosis and dermatitis around the neck, 'Casal's necklace', is the characteristic sign. 
which is characterised by dermatitis, diarrhoea, dementia and, if left untreated, may progress to death (the '4 Ds' serves as a mnemonic). ${ }^{1}$

Dietary deficiency is an important cause for pellagra in resource-limited countries. Other causes of niacin deficiency are alcoholism, bariatric surgery, malabsorption syndromes, carcinoid syndrome, Hartnup disease and certain drugs (isoniazid, ethionamide, chloramphenicol, 6-mercaptopurine, 5 -fluorouracil and azathioprine). ${ }^{2}$

The most characteristic finding of pellagra is the presence of dermatitis. The hyperpigmented rash is typically bilateral, symmetrical and limited to sun-exposed sites. Dermatitis over the sun-exposed area of the neck is classically described as 'Casal's necklace'. 23

The use of sunscreen and niacin supplements in our patient resulted in dramatic improvement at the 6-week follow-up (figure 4A-C).
Contributors SPM and CTR wrote the draft of the manuscript. GVS and VMS revised the manuscript critically for important intellectual content. All authors contributed to the literature review and approved the final manuscript for submission.

Funding The authors have not declared a specific grant for this research from any funding agency in the public, commercial or not-for-profit sectors.

Competing interests None declared.

Patient consent for publication Obtained.

Provenance and peer review Not commissioned; externally peer reviewed.

\section{ORCID iD}

Sharath P Madhyastha http://orcid.org/0000-0003-2821-3473

\section{REFERENCES}

1 Matapandeu G, Dunn SH, Pagels P. An outbreak of pellagra in the Kasese catchment area, Dowa, Malawi. Am J Trop Med Hyg 2017:96:1244.

2 Wan P, Moat S, Anstey A. Pellagra: a review with emphasis on photosensitivity. $\mathrm{Br} J$ Dermatol 2011;164:1188-200.

3 Ashourian N, Mousdicas N. Images in clinical medicine. pellagra-like dermatitis. N Engl J Med 2006;354:1614

Copyright 2020 BMJ Publishing Group. All rights reserved. For permission to reuse any of this content visit https://www.bmj.com/company/products-services/rights-and-licensing/permissions/

BMJ Case Report Fellows may re-use this article for personal use and teaching without any further permission.

Become a Fellow of BMJ Case Reports today and you can:

- Submit as many cases as you like

- Enjoy fast sympathetic peer review and rapid publication of accepted articles

- Access all the published articles

- Re-use any of the published material for personal use and teaching without further permission

Customer Service

If you have any further queries about your subscription, please contact our customer services team on +44 (0) 2071111105 or via email at support@bmj.com.

Visit casereports.bmj.com for more articles like this and to become a Fellow 